\title{
PENGEMBANGAN MULTIMEDIA PEMBELAJARAN TEMATIK INTEGRATIF UNTUK SISWA KELAS IV SEKOLAH DASAR
}

\author{
K.S. Diputra \\ Jurusan Pendidikan Guru Sekolah Dasar, \\ Universitas Pendidikan Ganesha, Indonesia \\ E-mail: sujendra.pgsd@gmail.com
}

\begin{abstract}
Abstrak
Penelitian ini adalah penelitian pengembangan yang bertujuan untuk mendeskripsikan hasil perancangan multimedia pembelajaran tematik Kurikulum 2013 untuk siswa Sekolah Dasar Kelas IV yang berkualitas dan siap untuk diimplementasikan dalam pembelajaran. Data dikumpulkan melalui instrumen penilaian pakar media pembelajaran, pakar desain multimedia, dan pakar pembelajaran tematik. Multimedia diujicobakan secara perorangan dan kelompok kecil untuk memperoleh respon user. Data dianalisis dengan analisis deskriptif kuantitatif. Hasil penilaian oleh pakar media pembelajaran, pakar desain multimedia, dan pakar pembelajaran tematik, menunjukkan bahwa multimedia yang dikembangkan sudah berkualifikasi baik. Hasil uji perorangan yang dilakukan oleh Guru Kelas IV SD Laboratorium Undiksha menunjukkan bahwa multimedia berkualifikasi sangat baik, dan hasil uji kelompok kecil diperoleh bahwa multimedia berkualifikasi baik. Hal itu berarti multimedia yang dikembangkan sudah siap untuk digunakan secara publik.
\end{abstract}

Kata kunci: Kurikulum 2013, Multimedia, Tematik

\begin{abstract}
This research belongs to Research \& Development study which aims at describing the steps in designing multimedia of thematic-multimedia instructions in Curriculum 2013 for the fourth grade of elementray schools' students which has quality and is ready to be implemented in classroom learning. The data of the quality was collected by conducting expert judgement by involving experts in learning media, multimedia, thematic learning. Multimedia was tried out individually and in a small group to collect the reponses toward the multimedia being developed. The data was collected by scoring rubric in which the data was analyzed using descriptive statistic. The results in expert judgment in learning media, multimedia, thematic learning show that the multimedia being developed had good quality. individual try out test was conducted by teachers of four grade students at Laboratorium Undiksha Elementary School which show that the multimedia had very good quality, and the results in small group test show that the multimedia had good quality.
\end{abstract}

Keywords: Curriculum 2013, Multimedia, Thematic.

\section{PENDAHULUAN}

Sejalan dengan perkembangan jaman, pembangunan dan teknologi, usaha peningkatan kualitas sumber daya manusia merupakan hal yang sangat penting. Peningkatan sumber daya manusia yang berkualitas untuk menunjang pembangunan nasional serta mengimbangi kemajuan
IPTEK merupakan tugas dari pendidikan. Oleh karena itu, sistem pendidikan sudah seharusnya mengembangkan prestasi dan berbagai macam keterampilan diantaranya kreativitas dan kesadaran global yang dikenal dengan "Kompetensi Abad 21" (Soland, Hamilton, \& Stecher, 2013). Kompetensi tersebut diantaranya adalah 
kemampuan memanfaatkan teknologi informasi dan komunikasi (information \& communication technology literacy skill), keterampilan berpikir kritis (critical thinking skil), keterampilan memecahkan masalah (problem solving skill), keterampilan berkomunikasi secara efektif (effective communication skill) dan keterampilan berkolaborasi (collaborate skill) (Chaeruman, 2010). Menyikapi kebutuhan pendidikan Abad 21, pemerintah melakukan penyempurnaan dalam sistem pendidikan nasional dengan memberlakukan Kurikulum 2013. Salah satu karakteristik pembelajaran di Kurikulum 2013 adalah memberlakukan pembelajaran tematik di pembelajaran di sekolah dasar untuk semua tingkatan kelas.

Pembelajaran tematik merupakan salah satu model pembelajaran terpadu yang menggunakan tema untuk mengaitkan beberapa mata pelajaran sehingga dapat memberikan pengalaman bermakna bagi peserta didik. Pembelajaran terpadu didefinisikan sebagai pembelajaran yang menghubungkan berbagai gagasan, konsep, keterampilan, sikap, dan nilai, baik antar mata pelajaran maupun dalam satu mata pelajaran (Permendikbud No. 57, 2014). Pembelajaran Tematik Kurikulum 2013 yang disebut dengan pembelajaran tematik integratif memiliki pendekatan yang berbeda dengan pembelajaran tematik pada kurikulum sebelumnya. Pendekatan yang digunakan untuk mengintegrasikan kompetensi dasar dari berbagai mata pelajaran yaitu intradisipliner, interdisipliner, multidisipliner, dan transdisipliner.

Pendekatan intra disipliner adalah Integrasi dimensi sikap, pengetahuan dan keterampilan secara utuh dalam setiap mata pelajaran yang integrasikan melalui tema. Inter disipliner yaitu menggabungkan kompetensi dasar-kompetensi dasar beberapa mata pelajaran agar terkait satu sama lain seperti yang tergambar pada mata pelajaran IPA dan IPS yang diintegrasikan pada berbagai mata pelajaran lain yang sesuai. Hal ini tergambar pada Struktur Kurikulum SD untuk Kelas I-III tidak ada mata pelajaran IPA dan IPS tetapi muatan IPA dan IPS terintegrasi ke mata pelajaran lain terutama Bahasa Indonesia. Multi Disipliner adalah pendekatan tanpa menggabungkan kompetensi dasar sehingga setiap mata pelajaran masih memiliki kompetensi dasarnya sendiri, yang tergambar pada Mata Pelajaran IPA dan IPS yang berdiri sendiri di kelas IV-VI. Trans Disipliner adalah pendekatan dalam penentuan tema yang mengaitkan berbagai kompetensi dari mata pelajaran dengan permasalahan yang ada di sekitarnya (Permendikbud No. 57, 2014).

Berdasarkan observasi yang dilakukan di beberapa sekolah dasar di Kabupaten Buleleng terkait pelaksanaan pembelajaran tematik Kurikulum 2013 di sekolah dasar, beberapa guru belum memanfaatkan media pembelajaran khususnya multimedia dalam melaksanakan pembelajaran. Hal tersebut juga dikuatkan oleh Lee (2006) yang menemukan bahwa para guru kurang dilatih untuk mengoptimalkan multimedia dalam pembelajaran. Permasalahan ini perlu mendapat perhatian serius mengingat pemanfaatan multimedia memiliki peranan yang penting dalam pembelajaran sekolah dasar yang mana optimalisasi multimedia mampu menjadikan pembelajaran lebih efektif. Gilakjani (2012) memberikan tiga alasan yang logis penggunaan multimedia dalam pembelajaran di kelas, yaitu menambah minat belajar siswa, meningkatkan pemahaman siswa, dan meningkatkan daya ingat siswa.

Multimedia merupakan gabungan digital teks, grafik, animasi, audio, gambar diam (gambar dan penarik perhatian visual), dan video. Melalui gabungan komponenkomponen tersebut, pengalaman belajar menjadi sesuatu yang interaktif yang mencerminkan suatu pengalaman dalam kehidupan sehari-hari (Aloraini, 2005; Vaughan, 2011). Beragam fitur-fitur yang dimiliki multimedia seperti video/audio, kuis, permainan, maupun animasi, mampu membantu guru dalam membelajarkan topik pembelajaran menjadi lebih variatif yang mana konten-konten multimedia memberikan dampak yang kuat terhadap pikiran dan perasaan siswa dalam belajar (Alfar, 2009; Nachimutu, 2012). Pemanfaatan animasi yang disertai dengan penguatan-penguatan verbal (penjelasan) sangat efektif dalam meningkatkan pemahaman materi/konsep yang dibelajarkan (Baharul Islam, Ahmed, Kabirul 
Islam, \& Shamsuddin, 2014). Beberapa kelebihan multimedia yang diimplementasikan dalam pembelajaran diantaranya adalah pembelajaran menjadi lebih interaktif, mampu menvisualisasikan materi yang selama ini sulit untuk diterangkan hanya sekedar dengan penjelasan atau alat peraga yang konvensional, memotivasi peserta didik, dan mampu memfasilitasi peserta didik belajar secara mandiri dalam memperoleh pengetahuan (Andresen \& Brink, 2013).

Berdasarkan pemaparan tersebut di atas, sangat penting menggunakan multimedia dalam pembelajaran di sekolah dasar sehingga anak sekolah dasar dapat memahami materi pelajaran dengan mudah. Sebagai contoh adalah multimedia mampu menghadirkan pengalaman langsung, misalnya untuk menjelaskan ikan didalam lautan, siawa dapat melihat langsung tayangan di multimedia dengan berbagai penjelasan suara dan efek animasi yang mengesankan seolah anak mengalami langsung kehidupan di dalam lautan atau untuk menjelaskan peristiwa gunung api meletus, guru dapat menampilkan video letusan gunung api yang terintegrasi dalam multimedia. Hal tersebut akan membantu anak dalam memahami dan mempelajari materi pelajaran dengan mudah dan menyenangkan. Konsep pembelajaran bermakna berbasis konstruktivisme akan mampu diimplementasikan dengan baik melalui pemanfaatan multimedia dalam pembelajaran (Shah \& Khan, 2015). Hal ini dikuatkan oleh beberapa temuan penelitian sebelumnya bahwa pembelajaran yang memanfaatkan ICT mampu membantu siswa memahami materi pembelajaran dan meningkatkan pemehaman konsep (Williams, Pedersen, \& Liu, 1998; Suwindra, 2004).

Oleh karena itu, fokus penelitian ini yang pertama adalah mendeskripsikan hasil pengembangan multimedia; dan kedua yaitu mengembangkan multimedia pembelajaran tematik Kurikulum 2013 yang berkualitas dan siap untuk diimplementasikan dalam pembelajaran. Multimedia yang dikembangkan adalah multimedia interaktif yaitu multimedia yang menyediakan struktur navigasi untuk memfasilitasi siswa berinteraksi dengan multimedia.

\section{METODE}

Jenis penelitian ini adalah jenis penelitian pengembangan (Research and Development). Tempat uji coba terbatas hasil pengembangan adalah SD Laboratorium Undiksha Kabupaten Buleleng, Propinsi Bali. Pengembangan penelitian ini merujuk pada model pengembangan Plomp (1997) yang meliputi fase investigasi awal; fase design/perancangan; fase realisasi/ konstruksi; fase tes, evaluasi \& revisi; dan fase implementasi. Penelitian ini tidak sampai pada tahap implementasi melainkan hanya sampai pada uji coba terbatas. Pada Fase Investigasi Awal ini dilakukan analisis masalah/kebutuhan terkait pengembangan multimedia dalam pembelajaran Tematik Kurikulum 2013 dan rancangan pemecahannya.

Pada Fase Desain/Perancangan dilakukan perancangan dan pembuatan desain multimedia menggunakan sumber maupun software pendukung yang diputuskan pada fase sebelumnya. Pembuatan multimedia memperhatikan kepraktisan dan kebermanfaatan yang merujuk pada dua kriteria yaitu kriteria pembelajaran dan kriteria penampilan. Desain multimedia pada fase ini masih bersifat hipotetik karena efektivitasnya belum terbukti dan akan dapat diketahui setelah melalui pengujian-pengujian. $\mathrm{Di}$ samping membuat desain multimedia, dibuat juga rancangan instrumen berupa lembar penilaian multimedia dan respon guru dan siswa terkait multimedia yang dikembangkan.

Dalam Fase Realisasi/Konstruksi ini tersusun media pembelajaran tematik interaktif yang selanjutnya disebut prototipe 1 yang siap divalidasi dan diujicobakan. Pada fase tes, evaluasi, dan revisi dimaksudkan untuk mengetahui dua hal, yakni: kualitas multimedia yang dikembangkan menurut pakar dan kualitas multimedia menurut sasaran pengguna multimedia yaitu guru dan siswa. Penilaian multimedia dilakukan oleh tiga pakar yaitu ahli media pembelajaran di lingkungan Fakultas IImu Pendidikan Undiksha, ahli desain multimedia di Jurusan Pendidikan Teknologi Informatika dan Komputer 
Undiksha, dan ahli pembelajaran tematik di jurusan Pendidikan Guru Sekolah Dasar Undiksha. Hasil penilaian ini kemudian dijadikan dasar melakukan revisi sebelum multimedia diujicobakan di SD Lab. Undiksha. Setelah prototipe direvisi kemudian dilakukan uji coba lapangan. Kegiatan uji coba lapangan dilakukan secara terbatas melibatkan kelompok kecil yang terdiri dari 25 Siswa Kelas V dan satu orang Guru Kelas IV SD Laboratorium Undiksha.

Data dikumpulkan melalui instrumen penilaian multimedia yang selanjutnya dianalisis menggunakan analisis deskriptif kuantitatif. Analisis deskriptif kuantitatif adalah suatu cara pengolahan data yang dilakukan dengan jalan menyusun secara sistematis dalam bentuk angka-angka atau persentase, mengenai suatu objek yang diteliti, sehingga diperoleh kesimpulan umum (Agung, 2012).

\section{HASIL DAN PEMBAHASAN}

Hasil peneltian berupa multimedia interaktif untuk pembelajaran tematik kurikulum 2013 yang dikembangan mengikuti langkah-langkah/fase berikut. Fase investigasi awal.

$$
\text { Hasil investigasi terhadap }
$$

pelaksanaan pembelajaran tematik

Kurikulum 2013, ditemukan beberapa masalah sebagai berikut. Pertama, bahan ajar yang digunakan guru terbatas pada buku guru dan buku siswa dalam pemerintah, yang menyebabkan pembelajaran masih terkesan kaku dan kurang variatif. Kedua, guru sudah berusaha menggunakan multimedia dalam pembelajaran walaupun masih sederhana berupa presentasi powerpoint yang dirancang oleh guru sendiri. Media presentasi yang digunakan masih memiliki keterbatasan dari sisi tampilan maupun kepraktisan mengingat pengetahuan guru yang masih kurang dalam menggunakan software-software pendukung untuk menghasilkan multimedia yang baik. Ketiga, belum tersedianya multimedia yang khusus dirancang untuk pembelajaran tematik. Keempat, siswa cenderung lebih tertarik untuk melihat dan mendengarkan media presentasi yang disajikan dibandingkan mendengarkan penjelasan yang disampaikan guru. Kelima, guru sering menerima keluhan dari orang tua siswa karena kesulitan membimbing anaknya belajar di rumah, yang disebabkan orang tua siswa tidak mengetahui konsep dari pembelajaran tematik dan terbiasa dengan pembelajaran parsial. Rencana penyelesaian dari masalah-masalah tersebut adalah mengembangkan multimedia pembelajaran tematik yang mampu menjadikan pembelajaran tematik lebih menarik serta mamfasilitasi siswa belajar secara mandiri. Multimedia yang dikembangkan adalah multimedia interaktif yang khusus dirancang untuk pembelajaran tematik Kurikulum 2013. Fase desain/perancangan.

Pada fase ini dipilih software utama pembuatan multimedia yaitu adobe flash cs 6 trial version yang dapat diunduh secra gratis di www.adobe.com. Tema yang dipilih sebagai tahap awal pengembangan multimedia adalah tema cita-citaku dengan subtema aku dan cita-citaku yang memuat tiga pembelajaran. Desain multimedia meliputi sistem navigasi (desain interface) yang ditunjukkan pada Tabel 1.

Tabel 1. Sistem Navigasi Multimedia

\begin{tabular}{cccc}
\hline No. & Halaman & Keterangan & File \\
\hline 1 & Induk & Penampung file multimedia & Aplikasi.fla \\
2. & Utama & Login/user & Halaman1.fla \\
3. & Menu & Sistem navigasi & Halaman2.fla \\
4. & Pembelajaran 1 & Materi 1 & Halaman 3.fla \\
5. & Pembelajaran 2 & Materi 2 & Halaman 4.fla \\
6. & Pembelajaran 3 & Materi 3 & Halaman 5.fla \\
7. & Evaluasi & Berisi soal evaluasi & Halaman 6.fla \\
8. & Laporan & Laporan nilai siswa & Halaman 7.fla \\
\hline
\end{tabular}




\section{Fase realisasi/konstruksi}

Fase ini dilakukan pembuatan prototipe multimedia sesuai dengan sistem navigasi dan tema yang dipilih. Beberapa gambar tampilan multimedia yang dirancang pada fase ini ditunjukkan pada Gambar 1, Gambar 2, dan Gambar 3.

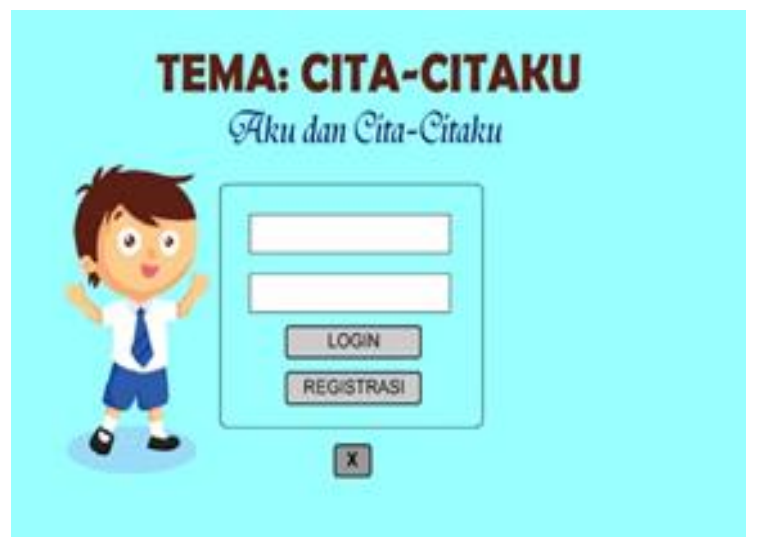

Gambar 1. Halaman Login Multimedia

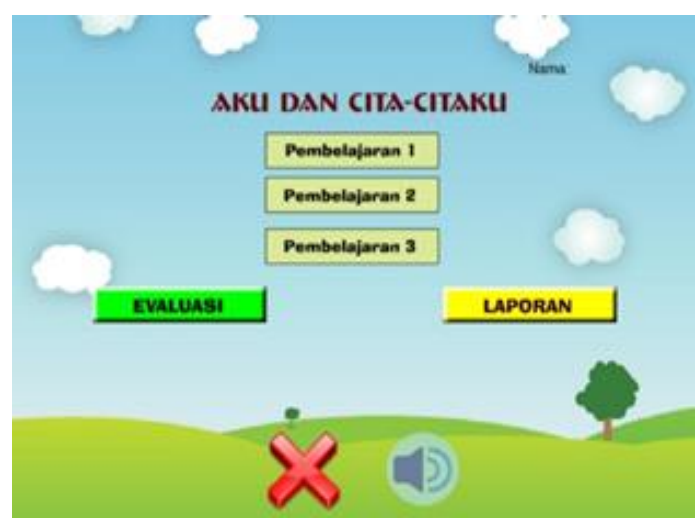

Gambar 2. Halaman Menu Multimedia

Gambar 1 merupakan halaman yang pertama kali muncul dalam multimedia.
Pada halaman ini, siswa mengisi form yang terintegrasi dengan halaman evaluasi.

Gambar 2 merupakan halaman utama berisi konten multimedia yang bisa dipilih oleh siswa (pengguna). Pada halaman ini terdiri dari tiga pembelajaran yang mana pada pembelajaran 1, 2, dan 3 masing masing memuat beragam konten diantaranya game sederhana, video, gambar, dan penjelasan seperti ditunjukkan pada Gambar 3.

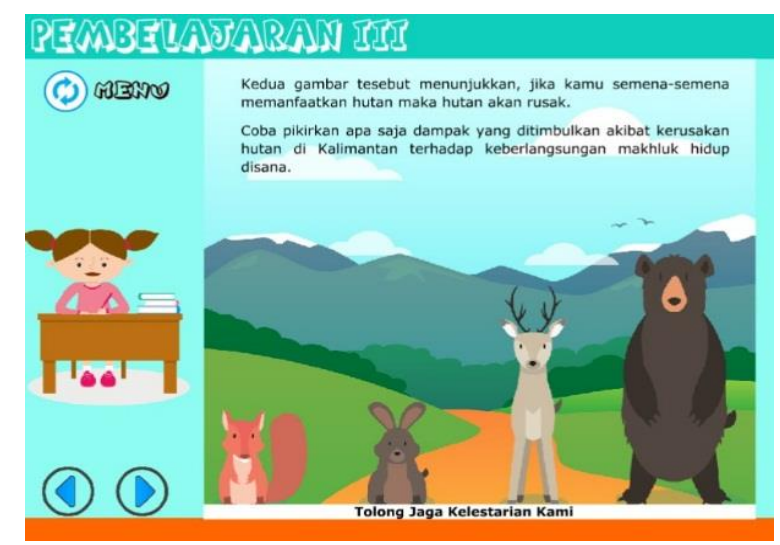

Gambar 3. Halaman "Materi 3" Multimedia

\section{Fase Tes, Evaluasi, dan Revisi}

Pengujian multimedia dilakukan oleh tiga pakar/ahli yang terdiri dari pakar media pembelajaran, pakar desain multimedia, dan pakar pembelajaran tematik untuk

mengetahui kualitas multimedia yang dikembangkan. Hasil penilaian kualitas multimedia secara ringkas dipaparkan pada Tabel 2.

Tabel 2. Penilaian Ahli Media Terhadap Multimedia

\begin{tabular}{clc}
\hline No. & \multicolumn{1}{c}{ Komponen Penilaian } & Skor \\
\hline 1 & Desain Pembelajaran & 14 \\
2 & Strategi Penyampaian Pesan & 33 \\
3 & Desain Antar Muka & 50 \\
\hline Skor Total & 97 \\
Skor Maksimal Ideal & 110 \\
Persentase Skor & $88.18 \%$ \\
\hline
\end{tabular}


Tabel 2 menunjukkan bahwa total skor

Hasil penilaian kualitas multimedia dari sisi kualitas multimedia oleh ahli media pembelajaran sebesar 97 dengan tampilan (desain) dipaparkan pada Tabel 3. persentase sebesar $88.18 \%$ yang berada dalam kategori baik.

Tabel 3. Penilaian Ahli Desain Multimedia

\begin{tabular}{|c|c|c|}
\hline No. & Komponen Penilaian & Skor \\
\hline 1 & Navigasi & 8 \\
\hline 2 & Tampilan & 26 \\
\hline 3 & Teks & 15 \\
\hline 4 & Gambar & 21 \\
\hline 5 & Audio & 28 \\
\hline 6 & Video & 24 \\
\hline 7 & Animasi & 18 \\
\hline 8 & User Friendly & 12 \\
\hline 9 & Kemasan & 19 \\
\hline \multicolumn{2}{|c|}{ Skor Total } & 171 \\
\hline \multicolumn{2}{|c|}{ Skor Maksimal Ideal } & 210 \\
\hline \multicolumn{2}{|c|}{ Persentase Skor } & $81.43 \%$ \\
\hline
\end{tabular}

Tabel 3 menunjukkan bahwa kualitas multimedia dari sisi tampilan diperoleh skor total sebesar 171 dengan persentase skor sebesar $81.43 \%$ dan berada pada kategori baik.
Hasil penilaian kualitas multimedia dari sisi konten pembelajaran dipaparkan pada Tabel 4 berikut.

Tabel 4. Penilaian Kualitas Konten Multimedia dengan Indikator Pembelajaran Tematik

\begin{tabular}{ccc}
\hline Bagian Multimedia & \multicolumn{2}{c}{ Kesesuaian Konten Multimedia dengan Kompetensi Dasar } \\
& Sesuai & Tidak Sesuai \\
\cline { 2 - 3 } & $\sqrt{ }$ & \\
\hline $\begin{array}{l}\text { Pembelajaran 1 } \\
\text { (Halaman3.swf) }\end{array}$ & $\sqrt{ }$ \\
Pembelajaran 2 \\
$\begin{array}{l}\text { (Halaman4.swf) } \\
\text { Pembelajaran 3 } \\
\text { (Halaman5.swf) }\end{array}$ & $\sqrt{ }$ \\
\hline
\end{tabular}

Berdasarkan Tabel 4 diperoleh bahwa konten-konten pembelajaran yang terdapat dalam multimedia sesuai dengan indikatorindikator di tiap pembelajaran tematik Kurikulum 2013 yang dikembangkan.
Hasil uji coba perorangan multimedia yang dilakukan oleh Guru Kelas IV SD Laboratorium Undiksha diperoleh hasil pada Tabel 5.

Tabel 5. Hasil Uji Perorangan oleh Guru Kelas IV SD laboratorium Undiksha

\begin{tabular}{clc}
\hline No. & \multicolumn{1}{c}{ Komponen Penilaian } & Skor \\
\hline 1 & Halaman opening & 16 \\
2 & Halaman utama/beranda & 15 \\
\hline
\end{tabular}




\begin{tabular}{clc}
\hline No. & \multicolumn{1}{c}{ Komponen Penilaian } & Skor \\
\hline 3 & Halaman deskripsi multimedia & 16 \\
4 & Struktur Kompetensi & 18 \\
5 & Pembelajaran 1 & 16 \\
6 & Pembelajaran 2 & 15 \\
7 & Pembelajaran 3 & 15 \\
\hline Skor Total & 111 \\
Skor Maksimal Ideal & 116 \\
Persentase Skor & $95.70 \%$ \\
\hline
\end{tabular}

Tabel 5 menunjukkan bahwa hasil penilaian kualitas multimedia yang dilakukan oleh guru mendapat skor 116 dengan persentase sebesar $95.70 \%$ dan berada dalam kategori sangat baik.
Hasil rangkuman uji coba kelompok kecil yang terdiri dari 25 Siswa Kelas V dipaparkan pada Tabel 6 .

Tabel 6. Hasil Uji Kelompok Kecil

\begin{tabular}{clc}
\hline No. & \multicolumn{1}{c}{ Komponen Penilaian } & Rata-rata Skor \\
\hline 1 & Halaman opening & 13.36 \\
2 & Halaman utama/beranda & 12.56 \\
3 & Halaman deskripsi multimedia & 13.28 \\
4 & Struktur Kompetensi & 16.88 \\
5 & Pembelajaran 1 & 13.52 \\
6 & Pembelajaran 2 & 13.32 \\
7 & Pembelajaran 3 & 13.36 \\
\hline Rata-rata Skor Total & 96.28 \\
Skor Maksimal Ideal & 116 \\
Persentase Skor & 83 \\
\hline
\end{tabular}

Tabel 6 menunjukkan bahwa hasil penelusuran kualitas multimedia berdasarkan respon siswa diperoleh bahwa rata-rata skor keseluruhan sebesar 96.28 dengan persentase sebesar $83 \%$ dan berada dalam kategori baik.

Hasil review yang dilakukan oleh ahli media pembelajaran, multimedia yang dikembangkan mendapat skor total sebesar 97 dengan persentase $88.18 \%$ dan berkualifikasi baik. Secara umum beberapa saran yang diberikan diantaranya pelengkapan beberapa komponen dalam kemasan multimedia, pencamtuman kelas

sasaran multimedia, penambahan nama pengembang, dan pencantuman sumber video pembelajaran yang terdapat multimedia. Oleh karena itu, secara umum multimedia sudah baik dan diperlukan sedikit revisi.

Hasil review dari ahli komputer dan desain multimedia dengan komponen penilaian meliputi sistem navigasi, tampilan keseluruhan, teks, gambar, audio, video, animasi, user friendly, dan kemasan, diperoleh skor total sebesar 171 dengan persentase skor sebesar $81.43 \%$ dan berkualifikasi baik. Saran yang diberikan untuk menyempurnakan multimedia yang dikembangkan adalah timing animasi yang perlu sedikit diperlambat pada pembelajaran 2 dan penggunaan font pada pembelajaran 3 sedikit diperkecil menyesuaikan dengan komposisi ruang tampilan multimedia. 
Hasil review dari sisi konten pembelajaran diperoleh bahwa semua konten pembelajaran sesuai dengan kompetensi dasar yang dipetakan pada tiaptiap pembelajaran. Hasil uji perorangan yang dilakukan oleh Guru Kelas IV SD Laboratorium Undiksha diperoleh skor total sebesar 111 dengan persentase 95.70\% yang berkualifikasi sangat baik. Hal ini mengindikasikan bahwa guru sebagai sasaran pengguna multimedia memberikan respon positif terhadap multimedia yang dikembangkan peneliti. Multimedia sangat sesuai dengan kegiatan pemebalajaran pada Buku Siswa yang disediakan pemerintah dan pemodifikasian kontenkonten di tiap pembelajaran termasuk pengintegrasian materi yang disampaikan dengan game memberikan nilai tambah multimedia yang dikembangkan. Multimedia mampu menpresentasikan pembelajaran tematik kurikulum 2013 dan sangat layak untuk dijadikan alternatif pembelajaran yang diimplementasikan di sekolah.

Hasil uji kelompok terbatas diperoleh rata-rata skor total sebesar 96.28 dengan persentase $83 \%$ berkualifikasi baik. Pengujian dilakukan oleh 25 Siswa kelas V SD Laboratorium Undiksha. Penggunaan Siswa Kelas V untuk mendapatkan prediksi efektifitas multimedia yang dikembangkan sebelum diujicobakan pada tingkatan kelas sasaran yaitu Kelas IV SD laboratorium Undiksha. Hasil uji kelompok terbatas mengindikasikan bahwa siswa memberikan respon positif terhadap multimedia yang dikembangkan. Materi-materi dalam multimedia sangat mudah dipahami, animasi yang diberikan sangat aktraktif, gambargambar karakter dalam multimedia sangat menarik, dan sangat cocok dipergunakan untuk belajar secara mandiri di rumah.

Hasil penelitian ini mendukung temuan dalam penelitian-penelitian yang terkait dengan pemanfaatan teknologi maupun multimedia dalam pembelajaran. Lee dan Keckley (2006) dalam penelitiannya menemukan bahwa multimedia memberikan dampak yang positif terhadap hasil belajar siswa dan mampu menumbuhkan motivasi siswa selama pembelajaran berlangsung.
Suwindra, Sujanem, dan Suswandi (2012) menemukan bahwa modul software multimedia interaktif yang diimplementasikan dengan strategi pembelajaran berbasis masalah mampu meningkatkan pemahaman konsep dan hasil belajar fisika Siswa Kelas XI SMA. Suarsana dan Mahayukti (2013) yang mengembangkan e-modul berorientasi pemecahan masalah dalam perkuliahan aljabar di perguruan tinggi menemukan bahwa malalui penggunaan e-modul berorientasi pemecahan masalah mampu meningkatkan kemampuan berpikir kritis mahasiswa. Selain itu, mahasiswa memberikan respons yang postif terhadap pembelajaran menggunakan e-modul yang dikembangkan. Terkait dengan pembelajaran di sekolah dasar, Shilpa dan Sunita (2016) menemukan bahwa multimedia mampu memberikan pendidikan yang interaktif di sekolah dasar dan mampu meningkatkan kualitas material atau kontenkonten pembelajaran di sekolah dasar.

\section{SIMPULAN DAN SARAN}

Hasil penelitian menunjukkan bahwa untuk merancang multimedia tematik Kurikulum 2013 dilakukan berdasarkan empat tahap, yaitu fase investigasi awal, analisis masalah/kebutuhan; Fase Desain, yaitu merancang desain navigasi serta pemilihan material multimedia (gambar, video, dan software pendukung); Fase Konstruksi, yaitu tahap pembuatan draf multimedia; dan Fase Tes, Evaluasi, dan Revisi, yaitu tahap pengujian draf multimedia oleh para pakar yang selanjutnya siap diujicobakan dan diimplementasikan pada skala yang lebih luas. Hasil pengujian draf multimedia oleh para pakar dan uji coba perorangan maupun uji coba terbatas pada kelompok kecil diperoleh bahwa draf multimedia yang dikembangkan memiliki kualitas baik yang selanjutnya siap diimplementasikan di kelas. Melalui penelitian ini disarankan bagi peneliti maupun praktisi pendidikan yang akan mengembangkan multimedia agar didampingi oleh praktisi di bidang desain multimedia sehingga multimedia yang dikembangkan menjadi lebih profesional. 


\section{DAFTAR PUSTAKA}

Alfar, I. 2009. Preparation and Production of Interactive Multimedia Software, Second Edition. Delta Computer Technology: Egypt.

Agung, A. A. G. 2012. Metodelogi Penelitian Pendidikan. Singaraja: Undiksha.

Aloraini, S. I. 2005. Distance learning. Alretha Press: Kingdom of Saudi Arabia.

Andresen, B. B. \& Brink, K. 2013. Multimedia in Education Curriculum. Moscow: UNESCO Institute for Information Technologies in Education.

Baharul Islam, M., Ahmed, A., Kabirul Islam, M. \& Shamsuddin, A. K. 2014. Child Education Through Animation: An Experimental Study. International Journal of Computer Graphics \& Animation (IJCGA), Vol.4, No.4.

Chaeruman, U. 2010. E-Learning dalam Pendidikan Jarak Jauh. Jakarta: Kemendiknas.

Gilakjani, A. P. 2012. The significant role of multimedia in motivating EFL learners' interest in English language learning. I.J.Modern Education and Computer Science, Vol. 4, No .4, hlm. 57-66.

Shah, I. \& Khan, M. 2015. Impact of Multimedia-aided Teaching on Students' Academic Achievement and Attitude at Elementary Level. US-China Education Review A, Vol. 5, No. 5, hlm. 349-360

Lee, L. 2006. Information and Communication Technologies: Transforming Views of Literacies in Early Childhood Settings. ISSN, Vol. 26, No. 1, hlm. 46-62.

Lee, Y., \& Keckley, K. 2006. Effects of a teacher-made multimedia program on teaching driver education: A case study. Teaching Exceptional Children Plus, Vol. 2, No. 5.

Nachimuthu, K. 2012. Pressures and Pressures of e-contents in Teaching. International Journal of New Innovations, Vol. 1, No. 2, hlm. 337340.
Peraturan Menteri Pendidikan dan Kebudayaan Nomor 57 Tahun 2014. Jakarta: Kemendikbud.

Plomp, T. 1997. Educational and Training System Design. Enschede: University of Twente.

Shilpa, S. \& Sunita, M. 2016. A study an interactive elementary education (36) with Multimedia. International Journal of Home Science, Vol. 2, No. 1, hlm. 214-215.

Soland, J., Hamilton, L. S. \& Stecher, B. M. 2013. Measuring 21st Century Competencies: Guidance for Educators. Tersedia di http://asiasociety.org/ diakses tanggal 20 Oktober 2016

Suarsana, I M., \& Mahayukti, G.A. 2013. Pengembangan E-Modul Berorientasi Pemecahan Masalah untuk Meningkatkan Keterampilan Berpikir Kritis Mahasiswa. Jurnal Pendidikan Indonesia. Vol. 2, No. 2, hlm. 264-275.

Suwindra, I. N. P. 2004. Penerapan Model Pembelajaran Fisika Interaktif Berbasis Web di Kelas I SMU Negeri 1 Singaraja. Jurnal Pendidikan dan Pengajaran. No 3, hlm. 85-95.

Suwindra, I N. P., Sujanem, R., \& Suswandi, I. 2012. Pengembangan Modul Software Multimedia Interaktif dengan Strategi Pembelajaran Berbasis Masalah untuk Meningkatkan Pemahaman Konsep dan Hasil Belajar Fisika Siswa Kelas XII SMA. Jurnal Pendidikan Indonesia. Vol. 1, No.1, hlm. 13-27.

Vaughan, T. 2011. Multimedia: Making It Works, Eight Edition. New York: McGraw-Hill Companies

William, D.C., Pedersen, S., \& Liu, M. 1998. An Evaluation of the Use of ProblemBased Learning Software By Middle School Students. Journal of Universal Komputer Science. Vol. 4, No. 4, hIm 466-483. 